\title{
Teologien ja uskonnontutkijoiden hybridikonferenssi - inspiraatioita, onnistumisia ja hämmennystä
}

Teologian ja uskonnontutkimuksen päivät 2020 Helsingissä 10.-11.9.2020

Konferenssiraportti

Siria Kohonen

7 nsimmäiset Teologian ja uskonnontutkimuksen päivät piti alun perin järjestää maaliskuussa 2020, noin viikko sen jälkeen, kun Suomen hallitus julisti poikkeustilan ja asetti maahan merkittäviä kokoontumisrajoituksia, etäopetusvelvoitteita ja rajoituksia maasta ja maahan liikkumiseen. Konferenssi peruttiin maaliskuulta pikavauhtia, mutta pian järjestäjät ilmoittivat, että tapahtuma pyritään järjestämään tavalla tai toisella syyskuussa.

Vielä elokuussa oli kuitenkin epäselvää, järjestetäänkö konferenssia perinteiseen tapaan paikan päällä, vai tuleeko tästäkin yksi koronavuoden etäkonferensseista. Lopulta järjestäjät päätyivät hybridiratkaisuun: konferenssiin sai osallistua sekä etänä että kasvokkain Helsingissä, mutta fyysisesti läsnäolevia kehotettiin tulemaan paikalle ainoastaan omana esityspäivänään ja muutoin seuraamaan esitelmiä etänä. Tieteiden talon saleissa noudatettiin osallistujarajoituksia, ja järjestäjien puolesta oli tarjolla kasvomaskeja.

Konferenssin paneelit järjestettiin kolmella eri tapaa: täysin Zoom-yhteyksien välityksellä, osittain Zoomissa siten, että osa puhujista puhui paikan päällä ja osa etänä, tai täysin paikan päällä. Kaikkia paneeleja pystyi kuitenkin seuraamaan Zoomissa ja sitä kautta pystyi myös esittämään kysymyksiä. Esitelmöintikielinä olivat suomi, ruotsi ja englanti.

\section{Ajankohtaisia aiheita ja teologiapuheen ohjeistusta}

Vaikka konferenssin ohjelma oli jo laadittu maaliskuussa, jouduttiin siihen ymmärrettävästi tekemään muutoksia ajankohdan vaihdoksen vuoksi. Järjestäjät käyttivät kuitenkin muutoksia hyväkseen, ja näin ohjelmaan saatiin myös ajankohtaisia puheenvuoroja koronatilanteesta ja sen vaikutuksista uskonnollisiin kenttiin. Konferenssi alkoi paneelikeskustelulla "Kirkot, uskonto ja hyvä elämä koronakriisin keskellä", jossa pohdittiin esimerkiksi inmisten henkistä hyvinvointia koronakriisin keskellä ja käytännön järjestelyjä kirkollisissa 
tilaisuuksissa, esimerkiksi ehtoollisen vietossa. Harvemmin konferensseissa käsitellään ihan näin tuoreita ja edelleen vallitsevia tilanteita tutkimusnäkökulmasta.

Keynote-esitelmiä oli kaksi, yksi kumpanakin päivänä. Chesterin yliopiston käytännöllisen teologian professori Elaine Grahamin esitelmä "Public Theology as Apologetics" keskittyi dialogisuuteen julkisen, kristillisteologisen puheen ja globaalin, moniuskontoisen yhteiskunnan erilaisten kontekstien välillä. Esitelmän otollisinta yleisöä olivat uskonnollisilla kentillä työskentelevät toimijat, jotka osallistuvat julkiseen keskusteluun, tai tällaisten keskustelujen tutkijat. Grahamin kommentit kristillisen teologian välittämisestä julkiseen keskusteluun vaikuttivat olevan ikään kuin ohjeistuksia puhujille, kuinka toimia moniuskontoisella tai sekularisoituneilla kentillä. Suomalaiseen uskontotieteeseen sekä Helsingin yliopiston teologisen tiedekunnan pääsääntöisesti tunnustuksellisuudesta erottautuvaan linjaan tottuneena tällainen puhe tieteellisessä konferenssissa tuntui minusta jokseenkin vieraalta. Luento oli nauhoitettu etukäteen.

PhD Robert Orsi (Northwestern University) esitelmöi puolestaan uskonnon ja teologian opettamisesta ja opiskelusta monien epävarmuuksien ja epäilysten maailmassa, nykyaikana. "The Study of Religion and Theology Beyond the Great Derangement" -esitelmä nosti esiin, kuinka myös uskonnon opettamisen ja opiskelemisen tulisi ottaa huomioon ympäröivä maailma ja sen ongelmat. Esitelmä lähetettiin osallistujille etukäteen tekstiliitteenä, ja keynote-ohjelman aikana Orsi oli etäyhteyden päässä vastaamassa yleisön esittämiin kommentteihin.

Kummatkin keynote-esitelmät oli järjestetty eri tavoin etäyhteyksin. Molemmat järjestelyt sekä etukäteen nauhoitettu luento että paperiversio esitelmästä - mahdollistivat sen, että keynote-esitelmiin pystyi perehtymään jälkikäteenkin. Näin tein myös itse, enkä siksi voi kommentoida, kuinka hyvin nämä eri tavat toimivat paikan päällä. Jälkikäteen seurattavat tallenteet olivat minusta kuitenkin yleisöystävällinen tapa hoitaa etäesitelmät: kuuntelija/ lukija pystyi seuraamaan esitelmää paremmin omassa tahdissaan, mikä auttaa erityisesti silloin, jos puheenaihe ei ole kovin tuttu.

\section{Kulttuurintutkimuksen monimuotoisia kysymyksiä}

Paneelisessioita konferenssissa oli yli viisikymmentä. Folkloristina jätin suosiolla syvimpiä teologisia opinkappaleita käsittelevät keskustelut vähemmälle, ja keskityin ennemminkin uskontotieteellisiin ja kulttuurintutkimuksen kannalta mielenkiintoisiin paneeleihin - sekä joihinkin keskusteluihin, jotka nyt vaan sattuivat henkilökohtaisesti kiinnostamaan. Parhaimmillaan paneeliesitelmät inspiroivat ajattelemaan omia tutkimusaiheita toisenlaisista näkökulmista.

Ensimmäisen päivän Runollinen jumalapuhe -paneelissa oli kiehtovaa pohdintaa, ja käsiteltyjä aiheita pystyi helposti pohtimaan myös kansanrunouden näkökulmasta. Erityisesti professori ja pappismunkki Serafim Seppälän puheenvuoro Salomon oodeista herätti pohtimaan puheenaiheen yhtäläisyyksiä itämerensuomalaisen kansanrunouden tutkimuksen kanssa. Seppälä muun muassa käsitteli runoutta uskonnollisen puheen kanavana, joka sallii rohkeita ja jopa egoistisia ilmaisuja puhujaltaan. Myös kirjallisuudentutkija Vesa Haapalan kommentaarinen puheenvuoro kielifilosofisesta näkökulmasta herätti ajatuksia. Wittgensteiniin nojaten Haapala hahmotteli, kuinka runokielessä ilmaistaan maailmankuvia, 
mytologioita, jumalakäsityksiä sekä uskomuksia maailmasta ja siitä saatavasta tiedosta. Myös kielen performatiivisuutta sivuttiin keskusteluissa.

Kansanusko, nykykulttuuri ja nykyhenkisyys -paneelissa taas käsiteltiin esimerkiksi mytologian ja kansanuskon käyttöä videopelimaailmassa, suomalaisten uuspakanallisten ryhmien yhteisöllisyyttä ja uskonnollisen ja populaarin festivaalikulttuurin sekoittumista. Helsingin yliopiston väitöskirjatutkija Toni Saarinen edusti tässä paneelissa hienosti folkloristiikkaa esitellessään salaliittoteorioita nykymaailman myytteinä, jotka myös saavat vaikutteita esimerkiksi Intian uskonnollisesta kulttuurista. Suomalais-karjalaisen kansanuskon näkökulmasta Turun yliopiston Jere Kyyrön esitelmä tietäjistä ja kalevalamittaisista loitsuista UnReal World -tietokonepelissä herätti pohdintoja siitä, mitä piirteitä kansanuskosta voi kätevimmin tuoda tietokonepelimaailmaan (paremman nuotion sytyttäminen tulen syntyloitsulla), ja minkälaiset piirteet jäävät tällaisessa popularisoinnissa helpommin huomiotta (yhteisölliset rituaalit).

Toisen päivän paneeleista erityisesti Uskonto ja tunteet sekä Uskonto ja huumori jäivät mieleen. Sekä tunteita että huumoria on viime aikoina käsitelty myös suomalaisessa folkloristiikassa, joten nämäkin paneelit herättivät kulttuurintutkimuksellisen mielenkiintoni. Konferenssin tunne-paneelissa pohdittiin muun muassa sitä, miten tunteita ja tunteiden eri muotoja voidaan ylipäätään tutkia. Paneelin puheenjohtajat Anne Birgitta Pessi ja Maija Penttilä kertoivat nojautuneensa tutkimuksissaan haastatteluaineistoihin, mutta uskontotieteilijä Outi Pohjanheimo nosti esiin, että emootiot ilmenevät ihmisten nonverbaalissa ilmaisussa. Huumori-paneelissa Turun yliopiston folkloristi Tero Ahlgren puolestaan käsitteli ihmisten omaehtoista, vernakulaaria ilmaisua Internet-meemien käytössä, ja kuinka uskontoa käytetään tällaisessa kielenkäytössä ajankohtaisten asioiden kommentoimiseen ja ilmaisemiseen virallisten medioiden ohi.

Oma esitelmäni sijoittui Mieli, merkitys ja yhteisö -paneeliin, jossa kuultiin niin kognitiivisen uskontotieteen edustajia (kuten allekirjoittanut) että sosiologisia näkökulmia uskonnontutkimukseen. Erityisesti mieleeni jäi maisterivaiheen opiskelijan, arkeologi Tomi Kuljukan uskontoarkeologinen esitelmä, jossa pohdittiin ihmismielen intuitiivisen ajattelun ja ajatusvinoumien mahdollisia vaikutuksia karhuun liittyvien esine- ja luulöydösten merkityksissä. Opiskelijalta vaatii rohkeutta lähteä tutkijoiden sekaan tieteelliseen konferenssiin, mutta Kuljukka lunasti esitelmällään paikkansa hienosti. Toivottavasti kulttuurintutkimuksen kenttä näkee hänet pian väitöskirjatutkijoiden joukossa.

Mielenkiintoisia paneeleja järjestettiin myös uskonnon ja sen tutkimuksen suhteista esimerkiksi ympäristökriisiin, sukupuolikysymyksiin ja politiikkaan. Eletyn uskonnon tutkimus, jolla on yhtäläisyyksiä kansanomaisen, omaehtoisen kulttuurin tutkimukseen, sai konferenssissa kaksi paneelia, joista toisessa elettyä uskontoa käsiteltiin teologian kannalta ja toisessa esiteltiin erilaisia näkökulmia ja tapaustutkimuksia.

\section{Miten hybridimalli toimi?}

Hybridikonfenressissa oli ilonsa ja ongelmansa. Päällisin puolin se jäi kuitenkin minulle mieleen positiivisena kokemuksena. 
Paneelien seuraaminen etänä mahdollisti sen, että päällekkäisten paneelien välillä pystyi liikkumaan vaivattomammin kuin täysin kasvokkain järjestetyissä konferensseissa. Lähes kaikissa sessioissa päällekkäisiä paneeleja oli yhdeksän, mikä ei toki ole vielä paljon verrattuna esimerkiksi vuoden 2019 European Association for the Study of Religions (EASR) -järjestön konferenssin 22 päällekkäiseen paneeliin. Usein kuitenkin jopa kaksi tai kolme päällekkäisyyttä saattaa tarkoittaa sitä, että jotain mielenkiintoista jää väistämättä väliin. Etäyhteydet helpottivat tätä ongelmaa osaltaan. Järjestäjien mukaan etäyhteydet vaikuttivat myös siihen, että paneeliyleisöjen keskimääräinen osallistujamäärä oli selvästi suurempi kuin normaalisti vastaavien konferenssien paneelisessioissa.

Kaikki konferenssin paneeliesitelmät myös tallennettiin muutamia yksittäisiä lukuun ottamatta, ja tallennukset olivat katsottavissa kolmen viikon ajan konferenssin jälkeen. Tämä taas mahdollisti sen, että niihin loppuihinkin esitelmiin, joita ei päässyt konferenssin aikana seuraamaan, pystyi palaamaan jälkikäteen. Tästä järjestelystä iloitsin erityisesti. Myönnän väsyväni konferensseissa helposti ihmispaljouteen, ja jossain vaiheessa tarvitsen väistämättä omaa aikaa sosiaalisesta kuormituksesta palautumiseen. Silloin voivat jäädä kaikista mielenkiintoisimmatkin esitelmät väliin.

Etäkonferensseissa ja hybridikonferensseissa yksi minun mielestäni oleellinen tieteellisten kokousten puoli kärsii kuitenkin väistämättä. Sosiaalinen interaktio jäi vähäiseksi. Konferensseissa yksi hienoimpia puolia on se, että voi kahvitauolla sanoa edes muutaman sanan ihailemalleen pitkän linjan tutkijalle, ja toisaalta saattaa tavata mielenkiintoisia nuoria tutkijoita, joiden kanssa jäädä juttelemaan paneelien jälkeen. Teologian ja uskonnontutkimuksen päivillä tämä puoli ei täysin uupunut minulta, koska osallistuin tapahtumaan ensimmäisenä päivänä paikan päällä, mutta huomasin, että verkostoituminen jäi selkeästi vähäisempään rooliin. $\mathrm{Ne}$, jotka osallistuivat konferenssiin täysin etänä, eivät saaneet irti sitäkään vähää.

Konferenssi-illallisesta ei luovuttu hybridikonferenssissakaan, vaikka osallistujamäärä oli selkeästi suppea koko osallistujamäärään verrattuna. Ravintola Sipulin Talvipuutarhassa oli kuitenkin paikalla useita kymmeniä inmisiä. Keskellä (tuolloin tosin kovin maltillista) pandemiatilannetta en voinut välttää sitä, että takaraivossani hyöri pieni epäilys siitä, onkohan tämä kuitenkaan ihan sallittua.

Illallisen aikana järjestäjätahot pitivät puheita. Järjestelytoimikunnan sihteeri Isto Peltomäki tiivisti hienosti ajatukseni koko konferenssijärjestelyistä ja tapahtuman mahdollistumisesta ylipäätään. Olin itsekin koko ajan varautunut teknisiin ongelmiin, viime hetken peruutuksiin, salimuutoksiin ja hämmennyksen tiloihin, mutta illallisella pystyin yhtymään Peltomäen sanoihin, jotka hän totesi selvästi itsekin ihmeissään ja asiaa kunnolla uskomatta: "Kaikki menikin hyvin."

\section{Siria Kohonen on teologian maisteri ja folkloristiikan väitöskirjatutkija Helsingin yliopistossa}

